\title{
Sexualidades nos Atos Apócrifos dos Apóstolos a partir Foucault
}

\author{
Alfredo dos Santos Oliva*
}

RESUMO

Proponho uma interpretação das sexualidades nos Atos Apócrifos dos Apóstolos, a partir de conceitos presentes nos escritos do filósofo francês Michel Foucault (1926-1984), seguindo a seguinte trajetória: (1) começo com algumas considerações mais teóricas sobre o modo como Foucault abordou a questão da sexualidade nos seus livros, artigos e cursos; (2) sigo o caminho ao falar um pouco sobre as fontes primárias que utilizarei na parte final do meu escrito e, por fim, me ocupo com diversas citações e exemplos retirados dos Atos Apócrifos dos Apóstolos, como um modo de tentar demonstrar a diversidade de conceitos e práticas relacionadas à sexualidade, em grupos alternativos de cristianismo do mundo antigo.

Palavras chave: Michel Foucault; Atos Apócrifos dos Apóstolos; Sexualidade Cristianismo Antigo; História Antiga.

ABSTRACT

I propose an interpretation of sexualities in the Apocryphal Acts of the Apostles, based on concepts present in the writings of the French philosopher Michel Foucault (1926-1984), following a path: (1) I begin with some theoretical considerations about how Foucault addressed the issue of sexuality in his books, articles and courses; (2) I follow the path by speaking a little about the primary sources that I will use in the final part of my writing, and finally I deal with various quotations and examples taken from the Apocryphal Acts of the Apostles as a way of trying to demonstrate the diversity of concepts and practices related to sexuality, into alternative groups of Christianity in the ancient world.

Keyword: Michel Foucault; Apocryphal Acts of the Apostles; Sexuality; Ancient Christianity; Ancient History.

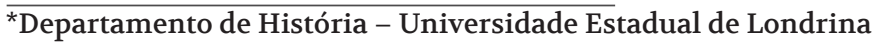




\section{Sexualidades em Michel Foucault}

Penso que um bom ponto de partida para explicar como o tema da sexuliadade emergiu nas pesquisas do filósofo francês Michel Foucault, é analisar a hipótese, muito em voga entre intérpretes contemporâneos do seu pensamento, de a sua "obra" ser composta de três eixos temáticos: arqueologia do saber, genealogia do poder e ética do cuidado de si. Isso porque o primeiro volume da sua "História da sexualidade" foi escrito sob influxo da questão do poder e o segundo e terceiro tomos a partir do debate sobre as técnicas do cuidado de si. Ou seja, embora sejam três livros sobre um mesmo tema (supostamente), o primeiro aparece no momento em que Foucault estava mais preocupado com questões relacionadas às técnicas de dominação (segundo eixo) e o segundo e terceiro quando se ocupava com as técnicas de si (terceiro eixo). Abaixo, vou me esforçar em explicar um pouco melhor as coisas.

O primeiro eixo temático de seus escritos é o que poderia ser denominado de arqueologia do saber, que compreendia pesquisas produzidas entre os anos 1950 e 1960. A principal estratégia metodológica do autor girava em torno do conceito de arqueologia, que poderia ser descrito como um procedimento de escavar verticalmente as camadas descontínuas de discursos com a finalidade de trazer à luz conceitos e práticas marginalizados; ou como um esforço para desvelar práticas discursivas que historicamente constituem determinados objetos ou sujeitos.

O segundo eixo temático pode ser denominado de genealogia do poder e englobava pesquisas realizadas ao longo dos anos 1970, quando Foucault passou a lecionar no Collège de France. Suas "precauções de método" gravitariam ao redor do conceito de genealogia, que pode ser descrito como um conjunto de procedimentos para conhecer o passado e desnaturalizar o presente; ou, ainda, como um mapeamento das ascendências do que hoje é pensado, dito e feito, não se tratando de uma interpretação, mas de uma história das muitas interpretações ocultadas ou sedimentadas.

Por fim, a ética do cuidado de si, que envolvia investigações iniciadas no fim dos anos 1970 e que estavam em curso quando Foucault morreu, no ano de 1984. Não havia nesse momento da vida do filósofo uma inovação de caráter metodológico, mas uma continuidade com procedimentos anteriormente utilizados, que poderia ser muito bem sintetizado pela expressão arqueo-genealogia.

O volume inicial da "História da sexualidade" é de 1976, quando Foucault pensava nas práticas de poder, sobretudo aquelas que eram externas ao sujeito e exerciam sobre ele um efeito de coerção. Os demais tomos foram finalizados às pressas, poucos meses antes do filósofo morrer, e estão relacionados às suas pesquisas sobre as técnicas ou práticas de si, formas de poder que o sujeito exercia sobre si mesmo. Assim, a linguagem, a forma de abordagem, bem como o hiato temporal entre o volume 1 e os 2 e 3 da sua "História da sexualidade", são muito distintos e grandes. 
Além disso, creio que o título das três obras é bastante enganador. Quem abre uma história da sexualidade talvez tenha em mente que encontrará uma descrição de práticas sexuais ou modos de expressão da sexualidade e suas variações no tempo e no espaço. Mas Foucault toma a questão como um problema filosófico e elabora perguntas do tipo: Como este campo foi gerido por poderes e discursos no mundo antigo e na atualidade (tomo 1)? Como a sexualidade foi atrelada à verdade e à subjetividade no mundo antigo (tomos 2 e 3)?

A temática da sexualidade em Foucault pode ser pensada de forma mais proveitosa se fizermos um corte transversal e procurarmos abordá-la a partir dos seus vários artigos dispersos, coligidos sobre a forma de "Ditos e Escritos", ao lado dos conhecidos três volumes sobre a história da sexualidade. Acho interessante complementar a leitura dos livros de Foucault em paralelo com suas entrevistas, assim podemos ver como o filósofo explicava seus próprios escritos e trajetórias teóricas. Em alguns momentos será necessário, inclusive, que mencionemos trechos de seus cursos ministrados no Collège de France, que foram transcritos e traduzidos para o português na sua totalidade. A atividade de Foucault como professor tem sido uma importante e prazerosa forma de inserção no seu pensamento, que, muitas vezes se projeta de uma maneira muito complexa nos livros que publicou em vida.

Além disso, proponho como estratégia didática, que abordemos três conjuntos de problemas e questões que perpassam a tríade que forma a sua "História da sexualidade", cujos aspectos são retomados nos seus artigos e entrevistas nos "Ditos e Escritos", assim como foram antecipados em seus cursos no Collège de France: sexualidade como dispositivo, sexualidade inflacionada por discursos e práticas e sexualidade como arte ou técnica de si.

Antes de detalhar o esboço acima estabelecido, gostaria apenas de mencionar o quanto o próprio Foucault se sentia reticente quanto ao título que deveria dar à serie acerca da qual escreveria três volumes. Se a denominou de "História da sexualidade" foi apenas por não encontrar nomenclatura mais adequada ou precisa. Retomar a sua indecisão é interessante porque nos aproxima, através dos nomes alternativos que cogitou, de uma compreensão da natureza do seu projeto. Digo isso porque quando, há mais de vinte anos, li os três livros sobre a história da sexualidade, tive uma impressão de que o que degustara não era uma história (historiografia), tampouco abordava o que eu compreendia por sexualidade.

Em entrevista concedida em 1977, logo depois de publicar "História da sexualidade 1", Foucault falava de um projeto que teria seis volumes. Sabemos que ele morreu sem levar a termo seu plano inicial e que demorou mais oito anos para publicar os dois tomos seguintes, que foram os últimos. Vemos, assim, na sua entrevista, tanto a dificuldade para escolher um nome para sua sequência, como uma projeção quantitativa que não pôde ser concretizada:

Esse livro é o único que eu escrevi sem saber antes qual seria o título dele. $\mathrm{E}$ até o último momento, eu não encontrei. A História da sexualidade é por falta de melhor. O primeiro título, que eu tinha mostrado a François Regnault, era Sexo e verdade. Renunciamos a ele, mas, enfim, isso era, apesar de tudo, meu 
problema: o que acontece no Ocidente para que a questão da verdade fosse colocada a propósito do prazer sexual? E é meu problema desde a História da loucura. Historiadores me dizem: "Sim, é claro, mas por que você não estudou as diferentes doenças mentais que se encontram nos séculos XVII e XVIII? Por que você não fez uma história das epidemias de doenças mentais?” Eu não consigo fazer com que eles compreendam que, com efeito, tudo isso é absolutamente interessante, mas que não era meu problema. Meu problema foi, a respeito da loucura, saber como se tinha podido fazer funcionar a questão da loucura no sentido dos discursos de verdade, isto é, discursos tendo estatuto e função de discursos verdadeiros. No Ocidente, é o discurso científico. É sob esse ângulo que eu quis abordar a sexualidade. (FOUCAULT, 2014, p. 59).

O trecho é revelador. Sua preocupação com a questão da sexualidade era a mesma que teve quando tratou do tema da loucura. Não olhou para as práticas culturais envolvendo a loucura, nem historiou as suas epidemias. Seu foco era o problema da conexão entre loucura e verdade. Do mesmo modo, não pesquisou as práticas sexuais e suas transformações no tempo, mas a o modo como a sexualidade emergiu como uma questão vinculada à verdade. Ele pensava como filósofo e não como historiador. A dimensão temporal apenas foi considerada em sua investigação à medida que ele olhava para as mais variadas direções em busca de observar como a sexualidade foi sendo construída por uma rede discursiva que buscava enunciar a verdade sobre ela e através dela. Quando olhou para os séculos mais recentes, viu que havia se formado uma ciência que reivindicava a veracidade para seus enunciados sobre a sexualidade ("História da sexualidade 1"). Ao observar a filosofia antiga, entre gregos e romanos, assim como o cristianismo em seus primeiros séculos de existência, percebeu que estes saberes também queriam pronunciar sua verdade sobre o sexo ("História da sexualidade 2 e 3").

Mais adiante, teremos oportunidade de esmiuçar as distinções entre os três tomos da sua "História da sexualidade". Agora precisamos passar às três questões que enunciei acima, começando pelo debate sobre o que seria um dispositivo, aspecto que envolveu, sobretudo, o primeiro livro da sua série.

\subsection{Sexualidade como dispositivo}

Acho interessante começarmos com a descrição do próprio Foucault sobre o que ele entendia por dispositivo e como ele funcionava no caso específico da sexualidade. Na citação que faço do autor, enumero os três aspectos que ele mesmo destaca em sua entrevista:

[1] O que eu tento descobrir sob este nome é, primeiramente, um conjunto decididamente heterogêneo, que comporta discursos, instituições, arranjos arquitetônicos, decisões regulamentares, leis, medidas administrativas, 
enunciados científicos, proposições filosóficas, morais, filantrópicas, em resumo: do dito, tanto quanto do não dito, eis os elementos do dispositivo. $O$ dispositivo propriamente é a rede que se pode estabelecer entre esses elementos. [2] Em segundo lugar, o que eu gostaria de descobrir no dispositivo é exatamente a natureza do laço que pode existir entre estes elementos heterogêneos. Assim tal discurso pode aparecer como programa de uma instituição, ora pelo contrário como um elemento que permite justificar e mascarar uma prática, que permanece, ela, muda, ou funcionar como interpretação secundária desta prática. Em suma, entre estes elementos, discursivos ou não, há como um jogo, mudança de posições, que podem eles também, serem muitos diferentes.

[3] Em terceiro lugar, por dispositivo entendo uma espécie - digamos de formação, que, em um dado momento histórico, teve por função maior responder a uma urgência. $O$ dispositivo tem, pois, uma função estratégica dominante. Isso pôde ser, por exemplo, a reabsorção de uma população flutuante que uma sociedade de economia do tipo essencialmente mercantilista achava incômoda: houve aí um imperativo estratégico, funcionando como matriz de um dispositivo, que se tornou pouco a pouco o dispositivo de controle-sujeição da loucura, da doença mental, da neurose. (FOUCAULT, 2014, p. 45).

Devolembrar, mais uma vez, que a citação é retirada de uma entrevista concedida por Foucault no ano de 1977, portanto logo depois do livro inaugural da sua "História da sexualidade", que é de 1976, e, assim, bem antes dos dois tomos finais, que, como sabemos, seriam publicados apenas em 1984. A pergunta do entrevistador é longa, mas, em síntese, gira em torno da especificidade da forma como o filósofo francês abordava a sexualidade, que era diferente de outros modos, como era o caso da biologia, da história das ideias e dos costumes ou história das práticas sexuais. Como seu interlocutor podia perceber, ele estava interessado no que denominou de "dispositivo de sexualidade". O inquiridor, depois de tanto contornar com considerações e precauções, chegou à questão: "Qual é para você o sentido e a razão metodológica desse termo: ‘dispositivo'?” E a resposta é o trecho que transcrevi na íntegra anteriormente.

O fato de o debate ter acontecido em 1977 é importante para compreendermos a resposta de Foucault. À época, sua principal preocupação ainda era a da questão do poder. Estamos diante do Foucault da sua segunda fase, a da genealogia do poder. Ele desenvolvia, ao longo dos anos 1970, uma série de reflexões sobre o modo como o poder funcionava. Ele se sentia muito desconfortável com a concepção marxista, que concebia o assunto de modo a considerálo como algo que emanava de um centro privilegiado, majoritariamente identificado com o Estado.

Em uma relação polêmica com os seguidores de Marx, propunha que o poder fosse compreendido como algo difuso e que, portanto, não emanava de nenhum núcleo. Além disso, era microfísico, portanto estava até mesmo onde não podia ser percebido de uma forma um 
tanto quanto óbvia. Por isso, passou a investigar os hospitais psiquiátricos, as prisões e os códigos jurídicos, que procuravam normatizar comportamentos e modos de vida, no sentido de criar normas e estabelecer quem era e quem não era normal (FOUCAULT, 2005). Foi através desse viés que chegou à sexualidade. Ele procurava, assim, ver como havia se constituído um dispositivo de sexualidade. Ele queria compreender como havia sido elaborada uma rede complexa de gestão da sexualidade, que envolvia instituições religiosas ou científicas, saberes espirituais ou acadêmicos, assim como espaços, como consultórios médicos ou psicológicos, hospitais e formas variadas de arquiteturas. Seu foco era tentar mapear como era o processo de elaboração de uma complexa trama que lançava suas teias sobre a sexualidade de modo a instrumentalizá-la por poderes.

\subsection{Sexualidade inflacionada por discursos e práticas}

De acordo com uma concepção desenvolvida por Foucault, sobretudo e ainda no primeiro tomo da sua trilogia, esta não foi reprimida ou silenciada, mas coberta por infinitas camadas de discursos e práticas.

Neste caso, não vejo trecho em que a tese seja colocada de forma mais clara do que no próprio texto inicial da sua "História da sexualidade":

É preciso, portanto, abandonar a hipótese de que as sociedades industriais modernas inauguraram um período de repressão mais intensa do sexo. Não somente assistimos a uma explosão de visível das sexualidades heréticas, mas, sobretudo - e é esse o ponto mais importante - a um dispositivo bem diferente da lei: mesmo que se apoie localmente em procedimentos de interdição, ele assegura, através de uma rede de mecanismos entrecruzados, a proliferação de prazeres específicos e a multiplicação de sexualidades disparatadas. Diz-se que nenhuma sociedade teria sido tão recatada, que as instâncias de poder nunca teriam tido tanto cuidado em fingir ignorar o que interditavam, como se não quisessem ter nenhum ponto em comum com isso. É o inverso que aparece, pelo menos numa visão geral: nunca tantos centros de poder, jamais tanta atenção manifesta e prolixa nem tantos contatos e vínculos circulares, nunca tantos focos de onde estimular a intensidade dos prazeres e a obstinação dos poderes para se disseminarem mais além. (FOUCAULT, 1999, p. 56-57).

O que acontece nos últimos séculos do mundo ocidental é que as sociedades se tornaram mais complexas e suas tecnologias de poder se transformaram e se aperfeiçoaram. Se nos mundos antigo e medieval a sexualidade era gerida, sobretudo, pelo cristianismo, a partir da modernidade, este fenômeno religioso passou a disputar a sua hegemonia com os diversos saberes científicos e acadêmicos, que se projetaram como igualmente legítimos. 
Além disso, as tecnologias de exercício de poder se adequaram aos novos tempos secularizados, ainda que se inspirem em modelos de gestão da religião. Parece que é assim, por exemplo, que Foucault compreendia a relação entre diferentes estratégias de poder, que seriam por ele denominados de "poder pastoral" e "poder disciplinar". Entre o fim da Idade Média e início da Moderna, funcionava um modo de exercício de poder que o filósofo francês chamava de "poder soberania", que foi lentamente substituído pelo "poder disciplinar" à medida que a Idade Moderna ia se difundindo. Em tempos mais recentes, uma nova tecnologia de poder estaria se formando e Foucault a denominou de "biopoder".

Estaríamos vivendo sob o influxo do "poder disciplinar" (em declínio) e do "biopoder" (ascensão). Não temos como estender muito este debate agora. Basta, para o momento, considerarmos que uma das características do "poder disciplinar" é a sua capacidade de individualização. Através de mecanismos de vigilância bastante difusos, as pessoas passam a vigiar uma às outras, de modo que todos observam e controlam a todos. Ora, esta forma de poder individualizante tem inspiração no modelo religioso do "poder pastoral", que, segundo Foucault, estava relacionado à figura do líder religioso que se ocupava com cada ovelha que possuía de forma pessoal.

O desenvolvimento de tais tecnologias de poder nos teria conduzido a um estado em que complexas redes de controle e vigilância mútua foram se estabelecendo, de modo que as sexualidades estariam enquadradas na sua tessitura. O importante é que não houve um silenciamento ou uma interdição da sexualidade, mas uma inflação de práticas discursivas de modo a regê-la e a controlá-la.

\subsection{Sexualidade como arte ou técnica de si}

Nos dois últimos volumes da história da sexualidade a perspectiva de abordagem do tema se desloca da questão do poder disciplinar para as técnicas do cuidado de si. O espaço de oito anos entre seu primeiro volume da "História da sexualidade" (1976) para os demais (1984) havia produzido um deslocamento nas investigações de Foucault. Deixou de se ocupar exclusivamente com os fatores externos e coercitivos do poder para se dedicar à sua dimensão interna. Foi assim que chegou à sexualidade: pensava nelas como uma forma de relação de si para consigo. Vou explicar melhor estas afirmações a seguir.

Foucault iria dedicar as pesquisas dos seus últimos anos de vida a explorar essa dimensão descuidada de seu trabalho - as técnicas de si. Tratava-se de investigar as ações empreendidas

pelo sujeito sobre si mesmo com vistas a transformar-se em algo distinto do que era. Não são apenas as forças externas (poderes) que cooptam ou submetem os sujeitos, mas há uma liberdade de autocriação "reservada" às pessoas. O filósofo desejava gastar alguns anos investigando essa nova dimensão, fato que se concretizou nos dois últimos volumes de sua "História da sexualidade", bem como pelos cursos que ministrou no Collège de France nos anos 1980, começando pelo que foi denominado (ironicamente) de "A hermenêutica do sujeito". 
O estudioso francês reconhecia que o trabalho de fazer uma genealogia do sujeito no mundo ocidental não deveria apenas se dedicar às disciplinas, como o fizera nos anos 1970, a exemplo do que está publicado em "Vigiar e punir". Deveria também debruçar-se sobre as técnicas ou práticas de si, como que produzindo uma visão mais integral e adequada da constituição das subjetividades.

Se quisermos analisar a genealogia do sujeito na civilização ocidental, é preciso considerar não apenas as técnicas de dominação, mas também as técnicas de si. Devemos mostrar a interação que se produz entre os dois tipos de técnicas. Talvez eu tenha insistido demais, quando estudava os hospícios, as prisões etc., nas técnicas de dominação. É verdade que aquilo que chamamos de "disciplina" é algo que tem uma importância real nesse tipo de instituições. Porém ela não passa de um dos aspectos da arte de governar as pessoas em nossas sociedades. Tendo estudado o campo do poder tomando como ponto de partida as técnicas de dominação, gostaria de estudar, durante os próximos anos, as relações de poder partindo das técnicas de si. (FOUCAULT, 2004a, p. 95).

O trecho acima permite concluir que Foucault ampliou sua visão do modo como as subjetividades eram construídas. Não se tratava de um processo unilateral - fatores externos ou internos exclusivamente -, mas da interação entre ambos. Se ele atentava a um novo universo temático a ser explorado, com isso não estava dizendo que tudo que investigara em décadas ateriores não tivesse sua importância. A nova dimensão - a que investiga as tecnologias de si deveria ser colocada lado a lado com as técnicas disciplinares. Eram dimensões complementares e não contraditórias.

Em outro texto, esmiuçou um pouco mais a maneira como funcionavam as técnicas ou práticas de si. Estas envolviam uma série de atividades, que precisavam ser repetidas à exaustão. Englobavam ações como a ascese, as abstinências de diversos tipos, as memorizações de textos canônicos ou filosóficos, as meditações, os silêncios etc.:

Nenhuma técnica, nenhuma habilidade profissional pode ser adquirida sem exercício; não se pode mais aprender a arte de viver, a technê tou biou, sem uma askêsis que deve ser compreendida como um treino de si por si mesmo: este era um dos princípios tradicionais aos quais, muito tempo depois, os pitagóricos, os socráticos, os cínicos deram tanta importância. Parece que, entre todas as formas tomadas por esse treino (e que comportava abstinências, memorizações, exames de consciência, meditações, silêncio e escuta do outro), a escrita - o fato de escrever para si e para outro - tenha desempenhado um papel considerável por muito tempo. (FOUCAULT, 2004b, p. 146). 
As pesquisas de Foucault em busca desse conjunto de técnicas de si foram empreendidas em direção à antiguidade clássica. Ele passou a investigar essas práticas entre os antigos gregos e romanos. $O$ filósofo francês se dedicou a um grande conjunto documental que abrangia um extenso recorte temporal, que ia do século V a.C. ao V d.C. Uma definição da expressão cuidado de si nos é apresentada por E. Castro em seu "Vocabulário de Foucault" para descrever esse conjunto de técnicas:

A expressão "souci de soi" (título do terceiro volume de Histoire de la sexualité) traduz o grego "epiméleia heautoû" (em latim "cura sui"); "cuidado de si mesmo" parece a melhor tradução para o português. O tema do cuidado de si foi consagrado por Sócrates; a filosofia posterior o retomou e, na medida em que ela mesma se concebeu como uma arte da existência, a problemática do cuidado ocupou o centro de suas reflexões. Esse tema acabou ultrapassando os limites da filosofia e alcançou progressivamente as dimensões de uma verdadeira cultura do cuidado de si. Os dois primeiros séculos da época imperial (séculos I-II) podem ser considerados como a idade de ouro da cultura do cuidado de si mesmo. (CASTRO, 2009. p. 92-93).

Assim, foi através de uma investigação sobre as técnicas de si que chegou ao tema da sexualidade no mundo antigo. Como filósofo, ainda perseguia a questão da verdade, mas agora procurava entender como ela estava atrelada ao tema da sexualidade. Interessava-se sobre como as pessoas eram instadas a declararem a verdade sobre seu sexo / sexualidade.

A partir dessas três questões presentes, de forma um tanto quanto dispersa, nos escritos de Michel Foucault, gostaria de visitar os Atos Apócrifos dos Apóstolos de modo a verificar se podemos encontrar a sexualidade funcionando do modo como o filósofo descrevia em um outro conjunto de textos do mundo antigo. Vou usar os aspectos mencionados e problematizados por Foucault como uma espécie de gabarito que guia o meu olhar para as fontes primárias e, assim, vou tentar perceber como a sexualidade funcionava no cristianismo do segundo século. Dirijamo-nos, enfim, às fontes primárias.

\section{As muitas sexualidades dos Atos Apócrifos}

Há uma excelente edição dos Atos dos Apóstolos Apócrifos. ${ }^{11}$ Trata-se de obra bilíngue, com tradução para o espanhol de escritos que estão, majoritariamente, em grego e com alguns poucos trechos em latim. Além disso, os textos antigos estão agrupados em três tomos e recebem uma longa introdução geral dos editores, assim como considerações sobre as particularidades

\footnotetext{
${ }^{11}$ Ao final deste artigo, no item "fontes primárias", o/a leitor/a encontrará a referência formal aos três volumes da edição espanhola que menciono, que também possui o texto original grego. Encontrei exemplares dos livros referidos na biblioteca da Universidade Metodista de São Paulo, em São Bernardo do Campo, mas devo ressaltar que possuo os mesmos em meu arquivo pessoal.
} 
de cada livro, ao longo dos volumes. Vou usar alguns dados dos editores dos Atos Apócrifos dos Apóstolos para analisar questões iniciais aos livros, além de mais alguns dados provenientes de outras obras de autores contemporâneos.

Os dois primeiros volumes da coleção trazem textos dos séculos II e III d.C. (talvez) e o terceiro tomo é uma nova coletânea com livros dispersos entre os séculos IV e IX d.C. Pela leitura dos três livros, tenho a impressão de que o primeiro e o segundo formam uma unidade original que foi acrescida de um terceiro tomo apenas a posteriori. Digo isso porque no primeiro volume há uma introdução geral aos Atos Apócrifos dos Apóstolos que diz respeito apenas a textos que compõem os tomos um e dois. Além disso, a numeração das páginas dos dois primeiros livros está em continuidade, mas o terceiro recebe paginação à parte. No início do terceiro volume há uma nova introdução que diz se tratarem de textos que podem ser designados como sendo pertencentes a uma segunda geração e, por isso, recebem um tratamento à parte.

Assim, é importante ressaltar que há uma primeira geração de Atos Apócrifos dos Apóstolos, composta dos Atos de André, Atos de João, Atos de Pedro (PIÑERO \& CERRO, 2004), Atos de Paulo e Atos de Tomé (PIÑERO \& CERRO, 2005), que são textos escritos no século II e (talvez) III d.C. E há uma segunda geração de livros, cuja lista é bem maior - Atos de Filipe, Martírio de Pedro, Atos de André e Mateus, Martírio de Mateus, Atos de Pedro e Paulo, Viagens e martírio de Barnabé, Atos de Tadeu, Atos de João, por Prócoro, Atos de Tiago o Maior, Atos de Tiago, Simão e Judas, Milagres de João, Paixão de Bartolomeu, Martírio de Nereu e Aquiles e Martírio de André (PIÑERO \& CERRO, 2011) - e foram escritos mais tardiamente, entre os séculos IV e IX d.C.

$\mathrm{Na}$ introdução geral, constante no primeiro tomo, os editores dizem que os escritos da primeira geração dos Atos Apócrifos procedem dos séculos II e (talvez) III d.C., quando ainda não havia se consolidado no cristianismo antigo a concepção de "verdadeira doutrina" ou mesmo não existia um consenso sobre o que deveria ou não ser considerado como conhecimento ortodoxo. Por isso, as vozes dos Atos Apócrifos dos Apóstolos da primeira geração pareciam ter pretensões análogas às dos autores do Novo Testamento (PIÑERO \& CERRO, 2004, p. 4).

Algumas marcas de seu contexto de escrita são descritos da seguinte forma pelos editores dos Atos dos Apóstolos Apócrifos:

Os AtAp [Atos Apócrifos] são um testemunho vivo do cristianismo da época. Um cristianismo pleno de luzes e sombras, temores e esperanças. Um cristianismo tentado pela sabedoria dos gregos ou atraído pelas doutrinas esotéricas do gnosticismo ou as aparências de perfeição ascética de certas práticas rigoristas. Mas é um cristianismo que segue recordando seus heróis e cultivando sua memória e suas doutrinas, apoiado em uma hierarquia e uma liturgia. (PIÑERO \& CERRO, 2004, p. 99). 
Os textos teriam sido escritos nessa ordem cronológica: André, João, Pedro, Paulo e Tomé. André seria o texto mais antigo e Tomé o mais recente da primeira geração. Para tratar especificamente do tema das sexualidades, vamos citar algumas passagens dos Atos Apócrifos de André e dos Atos Apócrifos de João (primeiro volume da edição mencionada acima) e dos Atos Apócrifos de Tomé (segundo volume). Vou mencionar aspectos específicos sobre cada uma destas três fontes antes de destacar alguns exemplos de alusão à sexualidade neles presentes.

Na primeira vez que li a primeira geração de Atos Apócrifos a minha reação foi de espanto diante da quantidade de debates e alusões à sexualidade. Dos três temas foucaultianos que me referi acima, creio que aquele que pensa a sexualidade como um campo inflacionado por discursos e práticas é o que pode ser percebido mais facilmente. O que vejo, logo à primeira vista, é que estes livros falam em demasia sobre sexo. Enfatizam a questão muito mais que o Novo Testamento, certamente levando às últimas consequências temas que são apenas aludidos no cânon cristão.

Mas não devemos pensar que, mesmo que os Atos Apócrifos possam ser compreendidos como textos que preservam a memória de grupos alternativos ou rivais daqueles que se cristalizariam nas formas institucionalizados de cristianismo, não tenham a pretensão de fazer a sexualidade funcionar como um dispositivo. Isto significa que práticas de poder foram enquadrando as questões relacionadas a sexo no cristianismo dos séculos II e III d.C. de modo que passaram a gerenciar a vida íntima das pessoas.

Se é verdade que práticas de poder externas procuram o tempo todo ter uma ingerência sobre as práticas sexuais dos cristãos primitivos, não é menos factível que elas eram pensadas e vividas pelos sujeitos como técnicas de si. Os primeiros seguidores de Jesus exerciam poderes sobre si mesmos de modo a se transformarem em pessoas distintas das que eram. Não são raras as narrativas em que sujeitos veem na abstenção sexual um dado fundamental de seu ser e os exercícios que exercem sobre si mesmos de modo a se manterem "castos" a qualquer custo. Creio que uma evidência desta ascese é a quantidade abundante de referências ao desejo ou ato sexual como fatos que atormentam severamente suas vidas.

\subsection{Atos Apócrifos de André}

Para os editores espanhóis dos Atos de André, trata-se de um escrito do ano 150 d.C., elaborado em Patras (Acaia), Síria ou Egito. Vejamos os seus argumentos:

Se aceitarmos estas semelhanças e por razões de crítica interna postulamos uma prioridade cronológica dos Atos de André, somos obrigados a pôr como término ad quem 190 d.C., uma vez que esta é a data aproximada de composição dos Atos de Paulo. Mas, levando em consideração as circunstâncias que temos notado, cremos que a data de origem dos Atos de André poderia girar em torno do ano de 150. (PIÑERO \& CERRO, 2004, p. 142). 
Com um pouco mais de flexibilidade, mas propondo algo que não estaria em conflito com a proposta acima de Piñero e Cerro, Trevijano indica a seguinte datação:

Se a utilização da obra pelo "Saltério maniqueu" mostra que não pode ser posterior ao século III, o modo pacífico pelo qual o autor mantém posições heterodoxas, sobretudo no campo da cristologia, permite a composição de sua obra entre o ano de 150 e 200, e mais próxima da primeira data do que da segunda. (TREVIJANO, 2009, p. 371).

Se os autores citados estiverem corretos, então estamos diante do mais antigo dentre os Atos Apócrifos. Assim, vamos tomar a data de 150 como a mais provável, sabendo que mais que isso seria querer ir mais longe do que podemos agora.

Além de André, há alguns outros que recebem certo destaque na narrativa apócrifa. Uma delas é Maximila, esposa do pro-cônsul de Acaia, que se tornou cristã a partir da pregação do apóstolo. Além disso, virou também defensora do encratismo, a rigorosa abstinência sexual, mas, como era casada, procurava uma forma de se livrar da sua incômoda "obrigação" conjugal. Nesse contexto é que ela é flagrada por Egeates, seu marido, em oração, pedindo a Deus o livramento da relação sexual.

Egeates se apressou para entrar no quarto suspeitando que Maximila ainda estivesse dormindo, pois estava apaixonado por ela. Mas Maximila estava em oração. E, quando o viu, se virou e olhava para o chão. Ele disse a ela:

- Dá-me, acima de tudo, a tua mão direita, que eu quero beijar à que, de agora em diante, não chamarei de esposa, mas de senhora. Pois, deste modo, terei o meu descanso em sua discrição e no carinho que sente por mim.

O pobre, ao encontrá-la em oração, pensava que estava orando por ele, uma vez que havia ouvido com surpresa o seu próprio nome durante a oração de Maximila. Mas o que Maximila dizia era o seguinte: "Livra-me, daqui adiante, da relação carnal imunda com Egeates e guarda-me pura e casta de modo que eu somente lhe sirva, meu Deus." Quando se aproximou com a intenção de beijá-la na boca, ela o rejeitou dizendo:

- Não é lícito, Egeates, que a boca de um homem toque a boca de uma mulher depois da oração.

O pro-cônsul, espantado com a seriedade da feição de sua mulher, afastou-se dela. E, depois de tirar a roupa de viagem, se retirou para descansar. Encostouse, pois, e como havia feito uma longa viagem, adormeceu. (Atos de André 14:1,2). (PIÑERO \& CERRO, 2004, p. 172-175). 
Destaco do trecho acima a sua fala durante a oração a Deus, quando pede que seja poupada da "relação carnal imunda", de modo que pudesse passar a viver de forma "casta". São palavras muito fortes e, certamente, serviam como demarcador da nova subjetividade que procurava construir através de sua ação sobre si mesma. Penso que, mesmo quando um poder é exercido pelo sujeito sobre si mesmo, como é o caso da narrativa acima, a sua exterioridade também deve ser levada em conta. Afinal, ela aprendeu com o apóstolo que as pessoas devem se manter castas. E se o texto circulava entre grupos cristãos primitivos, isto pode significar que os destinatários admiravam tais práticas. Eu diria que o poder sempre forma uma dobra, com uma força que age de fora para dentro do sujeito e outra que é acolhida e adulada pela pessoa. Assim, há duas forças agindo ao mesmo tempo, uma externa (práticas de poder / dispositivo) e outra interna (técnicas de si).

Temos que perseverar na análise da trama, pois há tantos outros fatos interessantes a serem observados. Adiante, percebemos que Maximila estava decidida a viver de forma casta, mas, como já era casada antes de se tornar cristã e encratista, teve que arquitetar um plano para que passasse a ser substituída por sua criada no leito conjugal e, consequentemente, no relacionamento sexual. Quando olho para a passagem abaixo tenho dificuldades em compreender os valores morais daquela mulher que, ao mesmo tempo em que sente uma profunda aversão pelo ato sexual, não se importa de mentir para seu marido, nem de subornar sua criada com recompensas para que fizesse por ela o que gerava nela nojo. Além disso, se o sexo era tão detestável, por que haveria de pagar alguém para que fizesse em seu lugar? Vejamos a narrativa dramática e divertida, ao mesmo tempo.

Maximila concebeu, então, o que segue. Mandou chamar uma criada muito bonita e exageradamente dissoluta, chamada Euclia, a quem disse o que havia pensado e desejava fazer:

- Você receberá de mim todos os favores que precisar se estabelecer um acordo comigo e cumprir o que lhe pedirei.

Disse, pois, a Euclia o que desejava e recebeu garantias dela. E, como queria viver dali adiante castamente, teve por um longo tempo este conforto. Assim, pois, como é costume da mulher arranjar-se com os adornos no inimigo, Maximila usou-os para adornar a Euclia e mandou que fizesse em seu lugar com Egeates. Este tinha relações com ela como se fosse sua esposa e logo permitia levantar-se e retirar-se de seu quarto; pois, esse era o costume de Maximila. Achando, pois, assim seu descanso e alegrando-se no Senhor por não ter que abandonar André, ocultou por muito tempo o que estava fazendo. (Atos de André 17:1,2). (PIÑERO \& CERRO, 2004, p. 176-177).

Claro que não seria justo julgar o texto e as personagens a partir de nossos valores contemporâneos. Se o fizesse, teria imensas dificuldades para estabelecer critérios que fossem 
razoáveis. Chamo atenção apenas para o fato de que estamos diante de um texto que funciona de acordo com uma "lógica" muito diferente das nossas. Sigamos na nossa análise.

Outro aspecto a ser destacado na descrição acima é a triangulação, relativamente frequente nos Atos Apócrifos, formada por esposa / marido / apóstolo. Em muitas situações narradas nestes livros, o martírio a que os anunciadores de Cristo são submetidos, está relacionado às consequências das suas pregações encratistas. Os principais alvos são as mulheres, muitas já casadas, outras em vias de contrair o matrimônio, que acabam por deixar maridos e pretendentes enfurecidos contra os pregadores da nova doutrina. Na maioria das vezes, os homens sedentos por sexo são retratados como importantes autoridades políticas do mundo antigo, fato que sempre confere ares de dramaticidade às narrativas, pois possuem poder para punir os pregadores da pureza sexual. Não é propriamente a adesão a Jesus que cria um rompimento entre a nova seguidora e o meio cultural em que está inserida, mas, sobretudo, a acolhida da prescrição de que o sexo é algo abominável.

Além disso, devo ressaltar que a rejeição da vida sexual ativa poderia não ser apenas um fato ligado ao campo da sexualidade, mas, talvez, seja também um fenômeno político. Em sociedades patriarcais, como as que pertenciam ao antigo Império Romano, estar livre do casamento, poderia ser uma forma de a mulher desfrutar de um pouco mais de liberdade ou mobilidade, embora isto também pudesse colocá-la em uma situação de fragilidade econômica e social. Não é por acaso que as mais fervorosas adeptas do encratismo são as mulheres e os maiores antagonistas são seus maridos ou pretendentes, quase sempre retratados como muito poderosos.

Com o passar do tempo, claro, a trama toda foi descoberta pelo marido, que ficou furioso, sobretudo com seus subalternos. De tão apaixonado que era pela esposa, não podia perceber que era ela quem concebeu e organizou todo o engodo. Sobrou para os empregados da casa. Assim, Egeates mandou torturar e crucificar os seus servos que haviam difamado e extorquido sua esposa em função da trama para ludibriá-lo no leito conjugal.

O pro-cônsul, depois de se informar diligentemente sobre tudo, soube que Euclia se deitava com ele como se fosse a sua esposa, de acordo com o que ela mesma havia confessado a seus próprios conservos. E, tendo-a interrogado, se inteirou de toda a verdade. Euclia, submetida a sofrimento, confessou tudo que havia recebido de sua senhora em troca de seu silêncio. Ficou muito indignado contra ela por ter se gabado na frente de seus companheiros e lhes haver dito aquelas coisas caluniando sua senhora - pois desejava que silenciasse sobre o assunto em função do carinho que sentia por sua esposa - mandou cortar a língua de Euclia, amputar-lhe os pés e as mãos e jogá-los fora. Euclia, depois de ficar vários dias sem receber alimento, virou presa dos cães. Aos seus outros escravos, que haviam contado o que aconteceu, mandou crucificar. (Atos de André 22:1,2). (PIÑERO \& CERRO, 2004, p. 180-181). 
A pena mais "branda" foi destinada aos servos que apenas contaram o que tinham ouvido. As medidas mais drásticas foram destinadas à criada que foi alvo de persuasão de sua senhora. $O$ texto me passa a ideia de que uma grande injustiça foi cometida, uma vez que foi Maximila a mentora de toda enganação. Além disso, fico com a impressão de que estamos diante de um marido cego de amor. Mas, o mais importante, é que no trecho vemos em funcionamento a hierarquia social do mundo romano. Miramos uma escrava manipulada por sua senhora, severamente torturada e condenada à morte por seu amo. Os demais escravos, são crucificados "apenas" por terem feito que as informações circulassem. O efeito hiperbólico produzido pela narrativa nos dá a dimensão da desumanidade com que os servos eram tratados em uma sociedade escravista.

Também André foi responsabilizado pelos infortúnios de Egeates. Sua pregação ascética foi interpretada como a principal causa dos problemas conjugais de Maximila e Egeates. Assim, o texto apócrifo afirma que: "Egeates, sem demora, ordenou encarcerá-lo dizendo: Já verá, calamidade, com que gratidão lhe devolvo estes favores que fez a Maximila." (Atos de André 26:3; PIÑERO \& CERRO, 2004, p. 186-187). Aparentemente, também o apóstolo foi condenado à morte, mas a sua posição na hierarquia social fez com que primeiro fosse encarcerado para que a pena pudesse ser executada depois. Ou, talvez, o encarceramento apenas fizesse parte da estratégia narrativa do autor do texto de modo a tornar as coisas mais dramáticas, ao produzir um efeito de retardamento dos fatos.

Egeates estava mesmo muito apaixonado por sua esposa e empreendia todos os meios para tê-la de volta no leito conjugal. Assim, propõe libertar André, caso Maximila restabelecesse o convívio marital e sexual com ele.

\begin{abstract}
Se pudesse ser aquela que era em outros tempos, convivendo comigo da forma que sabemos, dormindo comigo, unindo-se a mim, gerando filhos comigo, eu lhe favoreceria em tudo; mais ainda, libertaria o estrangeiro que tenho na prisão. Mas se você se negar, não lhe causarei mal algum, nem que quisesse; mas, àquele que você ama mais que a mim, eu o atormentarei muito mais. Pensa, Maximila, qual das duas soluções prefere e amanhã me responda. (Atos de André 36:2). (PIÑERO \& CERRO, 2004, p. 194-197).
\end{abstract}

Parece que Maximila se sentiu atraída pela proposta de Egeates. Talvez se sentisse responsável pela prisão de André e buscava um meio de livrá-lo da situação. Assim, foi atrás do conselho do apóstolo no cárcere, que a orientou a permanecer firme na abstinência sexual.

Não o faça; não ceda às ameaças de Egeates; não se deixe comover com seus discursos; não se deixe vencer por suas hábeis lisonjas; não queira se entregar aos seus imundos e pervertidos encantamentos. Apenas resista a todos os seus 
tormentos com os olhos fixos em nós durante algum tempo. E o verá entorpecido e consumido longe de você e de todos os seus congêneres. (Atos de André 37:2). (PIÑERO \& CERRO, 2004, p. 196-197).

Ao longo dos Atos de André vemos se desenvolver uma calorosa trama familiar, triangulada pela presença do apóstolo. Percebemos que quase tudo girava em torno do ato sexual, odiado pelos cristãos e loucamente ambicionado pelos que desconhecem o nome de Jesus. Pela defesa de sua adesão ao cristianismo, as pessoas eram capazes de mentir e subornar, apenas para não ter que se submeter à "terrível prática carnal". Por outro lado, para manter as relações conjugais, os que estão fora das bordas do cristianismo, eram capazes de grandes feitos para ter a vida conjugal reabilitada e, com ela, a tão desejada vida sexual ativa.

Uma forma de olhar os fatos é pelo prisma do poder. Uma mulher resiste aos caprichos de um homem ao se negar a fazer com ele o que o mesmo não deseja obter de nenhuma outra. Um homem influente, pró-cônsul, com um vasto poder político, não podia controlar, todavia, os desejos sexuais e afetivos de sua esposa (no caso, a ausência de apetite sexual!). Outro homem, apóstolo, sem poder político secular, mas com um imensurável capital religioso e persuasivo, consegue transtornar a vida pessoal de outro.

Sobrou fatalidade de verdade para os servos, a ponta debaixo da hierarquia social, política e econômica. Os que ouviram falar do engodo, "apenas" foram crucificados. A que participou da trama toda foi lentamente torturada até morrer.

Aparentemente, o personagem principal de toda trama é o "ato sexual", odiado por uns, estimado por outros, mas disputado por todos.

\subsection{Atos Apócrifos de João}

Piñero e Cerro dizem, inicialmente, que os Atos de João foram compostos no fim do século II d.C. (2004, p. 239), mas, um pouco adiante, afirmam que a época de composição de Atos de João poderia ser a década de 160 d.C., para a parte principal e mais "ortodoxa", enquanto os capítulos que trazem uma teologia que se aproxima do gnosticismo valentiano seriam escritos um pouco depois: "Por conseguinte, devemos situar os Atos de João, que são o modelo dos de Pedro, em 160 d.C. mais ou menos. A teologia original dos Atos de João, seu valentianismo não rígido, seu encratismo talvez moderado e seu modalismo doceta são apoios para esta datação." (2004, p. 287).

Para os pesquisadores mencionados, a intenção do autor dos Atos de João teria sido a de elaborar uma obra não polêmica, de caráter propagandístico e que poderia entreter e instruir, de forma agradável, ouvintes de tipo médio. O elemento novelesco se destacaria nos relatos, que possuem um tom erótico e amoroso. O responsável pela redação de Atos de João é desconhecido, mas pode ter sido alguém com uma cuidadosa formação retórica (2004, p. 255). 
Piñero e Cerro acham que há muitas dificuldades para classificar os Atos de João, do ponto de vista do seu gênero, mas é notável a sofisticação da educação literária de seu ator. Para eles, há uma estreita relação entre Atos de João e a Bíblia, especialmente com o Novo Testamento (2004, p. 257-260). O texto dos pesquisadores e editores dos Atos Apócrifos faz uma bela análise do conteúdo doutrinal de Atos de João, com especial atenção para as relações existentes entre este documento e o gnosticismo valentiano (2004, p. 260-275). Além disso, os autores fazem uma síntese muito interessante do sistema de crenças do gnosticismo / platonismo e indicam que no Livro I de "Contra os hereges", de Irineu de Lyon, há uma exposição do gnosticismo valentiano (2004, p. 267-268). Acrescentam que o autor (ou autores) presumido dos Atos de João não é totalmente gnóstico / platônico, mas também não se apresenta como um católico ortodoxo ou inserido no catolicismo eclesiástico (2004, p. 275).

Conforme já afirmei acima, a identidade do autor de Atos de João é desconhecida e o mesmo se pode dizer de um possível redator final do texto. Os eruditos espanhóis apresentam um debate sobre a localidade de composição de Atos de João. Dizem que poderia ser a Ásia Menor, o Egito ou Síria, e pensam que esta última é a mais provável (2004, p. 288-290).

O texto dos Atos de João é bastante extenso e diverso. Há várias seções e cada uma delas é ambientada em espaços ou cidades distintos. Em uma das situações, o apóstolo estava em Éfeso, onde convocava as pessoas para ouvirem um discurso em um estádio. Quando começou a proferir a sua longa e controvertida preleção, João se dirigiu aos "desvios" de conduta da população da cidade mencionando vários aspectos.

Você que se alegra com o ouro e sente prazer no marfim e nas pedras preciosas, quando vier a noite, poderá contemplar o que ama? Você que se deixa vencer (pelo gosto) de vestidos delicados, logo, quando deixar a vida, servirão para alguma coisa para aonde vai? Você, assassino, sabe que lhe espera um duplo e justo castigo depois que houver partido daqui. Igualmente você, mago, intrometido, ganancioso, saqueador, homossexual [ $\alpha \rho \sigma \varepsilon v o \kappa o \iota \tau\rceil]$, ladrão e os demais que participam deste coro, suas obras lhes conduzem até que topem com o fogo inextinguível, as densas trevas, o abismo do castigo e as ameaças eternas. Por ele, efésios, convertam-se, sabendo que também que os reis, os poderosos, os tiranos, os orgulhosos, os que derrotaram os inimigos ficarão desnudos aqui para sofrer os males eternos. (Atos de João 36:1-3). (PIÑERO \& CERRO, 2004, p. 330-331).

Destaco dentre os vários "vícios" da comunidade, a alusão que faz à homossexualidade, pois é o mesmo termo que aparece na Primeira Carta de Paulo aos Coríntios 6:9,10: “Ou não sabeis que os injustos não herdarão o reino de Deus? Não vos enganeis: nem impuros, nem idólatras, nem adúlteros, nem efeminados [ $\alpha \rho \sigma \varepsilon v о к о \iota\rceil \zeta]$, nem sodomitas, nem ladrões, nem avarentos, nem bêbados, nem maldizentes, nem roubadores herdarão o reino de Deus." 
Podemos perceber que nos Atos de João o termo é traduzido por homossexual, uma palavra contemporânea e politicamente correta, enquanto o tradutor do Novo Testamento usa a palavra efeminado, um tanto quanto inadequada. Um léxico (RUSCONI, 2003, p. 78) propõe que se verta o termo grego para o nosso idioma como homossexual ou sodomita, enquanto outro (MOUNCE, 2013, p. 120) é um pouco mais detalhado ao dizer que se refere a "um homem que pratica o sexo com outro homem, um sodomita, pederasta".

A palavra parece ser originária de duas outras $\alpha \rho \sigma \eta v$ e коıт. A primeira designa o gênero masculino, o macho, o varão ou pessoa de sexo masculino, enquanto a segunda alude ao leito ou relação conjugal ou, ainda, quando seu uso é metonímico, pode referir-se à relação sexual ou coito (MOUNCE, 2013, p. 120 e 369; RUSCONI, 2003, p. 78 e 270). Em síntese, é o homem que desfruta do leito com uma pessoa do mesmo sexo. No mundo antigo, parece que a designação de efeminado era mais adequada, enquanto no nosso usamos mais a palavra homossexual. Mas o que importa no momento é que os dois textos (1Coríntios e Atos de João) se referem aos autores de tais práticas de forma negativa. O segundo poderia ser uma reverberação do primeiro, por motivos óbvios de caráter cronológico. Enquanto a Primeira Carta de Paulo aos Coríntios é de meados do século I d.C., os Atos Apócrifos de João são da segunda metade do século seguinte. Do mesmo modo que a afirmação de Paulo de que não se casar é melhor do que contrair matrimônio (1Co 7:25-40), poderia ter sido interpretada pelos cristãos do segundo século d.C. de forma a praticarem uma radical vida de abstinência sexual, a referência que fazia à exclusão do Reino de Deus dos "efeminados" poderia ter sido vista como uma advertência para que tal prática fosse vista como incompatível com uma subjetividade cristã.

A condenação da homossexualidade não é o único aspecto que caracterizava a ascese dos Atos de João. Outro relato interessante do livro é a história de um rapaz que matou seu pai por estar possuído por um demônio que o incitava ao "adultério". Sabemos que, mais adiante, o jovem se matou ao perceber que havia cometido um erro. Para remediar a situação, o narrador diz que João o ressuscitou, assim como a seu pai. Observemos agora este trecho inicial, pois o drama está apenas começando. Seu desenlace será, além de trágico, surpreendente.

No dia seguinte, João viu em um sonho que havia viajado quase cinco quilômetros fora dos portões. Não tomando conhecimento dele, levantou-se muito cedo e, junto com os irmãos, pôs-se a caminho. Um camponês, advertido por seu pai que não tomasse para si a esposa de um companheiro de trabalho, ameaçava a si mesmo de morte. O jovem, não tolerando a repreensão do seu pai, logo o golpeou e o deixou sem alento (Atos de João 48:1). (PIÑERO \& CERRO, 2004, p. 386-389).

Logo após João interferir na história, anunciar o evangelho ao rapaz e restaurar a vida aos que a haviam perdido, a narrativa chega ao ápice da dramaticidade quando o jovem parricida 
se castra e joga sua genitália na cara da mulher com quem cometeu "adultério". Sabemos que João reprovou o que ele fez, dizendo que ele agiu por inspiração demoníaca.

O jovem, ao contemplar a inesperada ressurreição de seu pai e sua própria salvação, pegou uma foice, cortou suas partes, correu para a casa em que estava a adúltera e as jogou na cara dela com as seguintes palavras:

- Por sua culpa eu me converti no assassino do meu pai, assim como vocês e de mim mesmo. Aqui está o que causou tudo isso. Deus em sua misericórdia me fez conhecer o seu poder. (Atos de João 53:1). (PIÑERO \& CERRO, 2004, p. 392-303).

Que outro símbolo de adesão irrestrita ao encratismo alguém poderia dar do que cortar o próprio órgão genital e lançá-lo na face da mulher com quem, pouco antes, havia desfrutado do prazer sexual? Que o texto quer transmitir com este drama? Que o sexo deixa as pessoas "loucas"? Que a única forma de estar fora deste jogo é renunciar totalmente ao prazer? Tenho a impressão de que o autor do texto tenta o tempo todo mostrar que a sexualidade é um trem fora dos trilhos prestes a tombar a qualquer momento e a melhor forma de evitar problemas com ela é, única e exclusivamente, a renúncia total.

Se a citação da homossexualidade em um contexto negativo e um relato de homicídio e autocastração podem parecer situações extremas para um texto cristão, que dizer de uma história que envolve necrofilia? Então, temos outro exemplo do encratismo rígido. É o relato de Calímaco, que ficou enamorado por Drusiana e violou a sua sepultura, com a cumplicidade de Fortunato, o administrador do seu marido, com a intenção de manter relações sexuais com sua admirada. Vejamos os detalhes dessa "curiosa" história.

Embora fosse casada, Druisiana era severamente cobiçada por Calímaco. Como não pôde tê-la em vida, pensava em realizar seu desejo mesmo após a sua morte. Para isso, contava com a ajuda do administrador do marido enlutado, que o texto diz que era um homem corrupto.

Enquanto João continuava a discursar diante dos irmãos, procurando ensinálos o desprezo pelas coisas passageiras, o amante de Druisiana - inflamado por um terrível desejo e pela ação do multiforme Satã - comprou com quantia razoável o administrador de Andrônico, que era corrupto. Este abriu a tumba de Drusiana e lhe permitiu executar no corpo inerte a ação proibida. Como não tinha podido fazê-lo enquanto ela vivia e ainda se sentia atraído por seu corpo mesmo depois de morto, dizia para si mesmo: "Já que não quis unir-se a mim estando viva, desonrarei seu cadáver após a morte”. Com estes pensamentos e disposto a cometer a impiedade, graças ao administrador corrupto, pulou com ele para o interior do sepulcro. Abriram a porta e começaram ambos a desnudar o cadáver de suas vestes sepulcrais, enquanto diziam: No que você saiu ganhando, Drusiana desgraçada? Não poderia ter feito, viva, o que talvez 
não lhe haveria proporcionado nenhuma pena, se não tivesse realizado voluntariamente? (Atos de João 70:1,2). (PIÑERO \& CERRO, 2004, p. 412-413).

$O$ relato é de uma crueldade sem medida. A primeira parte da narrativa parece até dizer que Calímaco já teria cometido a necrofilia, mas o desenrolar dos fatos fica evidente que a intenção foi apenas permitida, mas não realizada. De qualquer forma, o violador destila maldade até mesmo com suas palavras ao chamar sua cobiçada de "desgraçada".

O texto diz, mais adiante, que Calímaco e Fortunato morreram e João foi visitar a sepultura e viu Jesus cuidando do corpo de Drusiana. Assim, o plano de Calímaco foi descoberto, ele morreu por causa de sua desmedida maldade, mas, como o autor do texto sempre tem uma solução para problemas insolúveis, ele foi ressuscitado. Como reviveu, teve a oportunidade de se arrepender de suas ações e intenções.

Na sequência, os Atos de João mostram a conversão de Calímaco, que confessou a intenção que tinha de violar o corpo de Drusiana, mas que Cristo não permitiu. $O$ vilão se diz arrependido e desejoso de mudanças (Atos de João 76:1-6; PIÑERO \& CERRO, 2004, p. 418-423). O drama termina com a ressurreição de Drusiana e a de Fortunato (Atos de João 79:1-3; PIÑERO \& CERRO, 2004, p. 424-427). Mas, como este último não se compungiu de suas faltas, passou para a morte de forma definitiva (Atos de João 84:1,2; PIÑERO \& CERRO, 2004, p. 430-433).

Por fim, ao menos em termos daquilo que estamos focalizando, o tema da sexualidade, chegamos a uma longa oração de João, onde ele mesmo destaca a sua pureza sexual. Ele ainda agradece a Deus por ter impedido que se casasse, no passado, quando tinha intenção de fazê-lo. Voltamos ao tema da valorização do encratismo, onde estar fora do casamento, e não apenas deixar o desejo sexual de lado, era algo fundamental.

Você que até a presente hora me guardou limpo e puro de todo contato com mulher. Você que, quando desejava me casar na minha juventude, me apareceu e disse "Preciso de você, João". Você que colocou diante de mim uma enfermidade corporal quando ia me casar. Você que, quando eu, desobediente, pretendia pela terceira vez me casar, me impediu e logo na terceira hora me disse no mar: "João, se você não fosse meu, eu teria permitido que se casasse." Você que durante anos me cegou procurando a ocasião de chorar e suplicar na sua presença. Você que ao terceiro ano abriu os meus olhos e mente e concedeu graciosamente olhos saudáveis. Você que, quando recobrei a visão, determinou que me seria odioso até mesmo olhar para uma mulher. (Atos de João 113:1,2). (PIÑERO \& CERRO, 2004, p. 450-453).

Vemos em um único livro menção à homossexualidade em um contexto que o enquadra de forma pejorativa, assassinato e automutilação genital, necrofilia e, por fim, apologia do encratismo. Seria possível encontrar em apenas um escrito uma abordagem tão dramática 
do sexo? Que deseja o autor ao narrar tais fatos dessa maneira? Dizer que o ato sexual deixa as pessoas insanas a ponto de matar, se autodestruir ou violar a sepultura de uma mulher cobiçada? Parece que estamos diante de um texto que usa a força da persuasão da hipérbole para convencer as pessoas do grande mal que o sexo pode causar!

Mesmo que o autor exagere de modo a conseguir um efeito marcante sobre as pessoas, $o$ resultado não poderia ser oposto? De tão "picante" o escrito me parece mais capaz de estimular a fantasia sexual do que contê-la. De qualquer forma, a alternativa parece estar colocada para a formação de uma subjetividade cristã: ou alguém é um seguidor de Jesus ou vai desfrutar dos prazeres da vida sexual. A interdição é bastante ampla: nada de relações afetivas com pessoas do mesmo sexo, o mesmo vale para jovens solteiros que estejam "ardendo" em desejo sexual ou até mesmo pessoas casadas. O retrato que o autor dos Atos de João traça da sexualidade é a de que ela é horrenda, perigosa e sempre conduz a atos vergonhosos e constrangedores, chegando ao extremo do ridículo quando um homem viola a sepultura de uma mulher bela e cobiçada.

\section{Considerações finais}

Se retomarmos as considerações de Foucault sobre a sexualidade, como se elas formassem uma espécie de gabarito vazado que usamos para contrastar com o que observamos nos Atos Apócrifos, creio que teremos um interessante quadro.

A pintura começaria a ser delineada a partir do conceito de dispositivo, que serviria para focarmos a sexualidade dos Atos Apócrifos. Creio que nos veríamos diante de uma extensa teia que se projeta sobre o campo da sexualidade. O cristianismo, uma religião nascente e desempoderada, começava a formar uma rede de poderes microfísicos sobre a sexualidade do mundo pagão. A tessitura é composta de elementos colhidos no Novo Testamento, talvez de Paulo, quando recomendava que as pessoas fariam melhor coisa se permanecessem solteiras. Quiçá, um outro fio fosse desfiado a partir de correntes filosóficas como o estoicismo ou o epicurismo, já inventoras de práticas discursivas que tentavam reger a vida sexual das pessoas de seu tempo através da continência. Quem sabe, ainda, também fizesse parte de toda tessitura o silêncio sobre a vida sexual e afetiva de Jesus, afinal os Evangelhos Canônicos nada nos dizem sobre ele ser solteiro ou casado, nem sobre seus laços afetivos. Creio que o mestre inspirador do cristianismo, no retrato que foi construído pelos textos aceitos pela grande tradição, estava mais próximo, se pensarmos na sua sexualidade, de um cínico, no sentido de que não parecia manter nenhum vínculo social que fosse significativo. Talvez esta imagem de Cristo sem família e sem laços afetivos tivesse alimentado a fantasia dos cristãos primitivos a viverem da mesma forma, de modo a se sentirem estimuladas a romperem os laços afetivos e sexuais que mantinha quando conheceram o seu Senhor.

Se persistirmos em usar o campo conceitual foucaultiano como um molde vazado que nos permite olhar para as representações da sexualidade nos Atos Apócrifos, agora dando destaque para a inflação de discursos e práticas sobre o tema, veremos como os primeiros cristãos não se 
cansaram de normatizar as práticas cotidianas de suas seguidoras. As mulheres são descritas como as mais vorazes adeptas do encratismo, para infelicidade de seus maridos e pretendentes. Vemos uma enxurrada de prescrições e interditos sobre sexo que nos fazem como que ver um mundo cindido entre dois grandes grupos: os que aderem às práticas encratistas cristãs e os que as elas se opõem. Algumas delas parecem felizes por se preservarem castas e outras irritadas e enlouquecidas por não poderem fazer sexo em função dos efeitos da pregação cristã. De um lado, quase sempre, mulheres tramando sobre como se livrar do ato sexual, de outro, homens "à beira de um ataque dos nervos", sedentos por sexo, a ponto de prender pessoas, violar sepulturas ou cortar partes de seus corpos em protesto. De qualquer forma, apenas não se vê silêncio sobre a vida sexual, demonstrando que Foucault acertou em cheio quando disse que o problema do ocidente não é a repressão ou o sigilo que marcam o campo da sexualidade, mas uma profusão de práticas, discursos e prescrições.

Por fim, o debate mais profícuo, no meu modo de ver, é aquele que apontava para a sexualidade como uma das muitas tecnologias de si. Quando contemplamos os Atos Apócrifos, o que mais vemos é o quanto foi se constituindo uma ascese em torno do sexo. Uso a palavra ascese não apenas no sentido de que as pessoas procuravam viver de forma casta, mas no sentido de que a vivência da sexualidade envolvia uma série de práticas empreendidas por um sujeito sobre si mesmo de modo a se transformar em algo distinto do que era. Tenho a impressão de que a sexualidade foi a área que melhor serviu para a construção de uma subjetividade tipicamente cristã entre meados do segundo século e o início do terceiro da era cristã, de acordo com nossas fontes primárias. As subjetividades configuradas pelo cristianismo nascente eram "puras" enquanto as que estavam fora dos seus domínios eram ensandecidas. Vejo os fatos como se os autores dos textos analisados acima quisessem passar a mensagem de que, a menos que uma pessoa fuja do "vergonhoso ato", ela necessariamente desembocará nas ações mais absurdas possíveis, como praticar a necrofilia, o adultério, a homossexualidade ou ter que se expor à morte para satisfazer seus desejos. Certamente, há todo um exagero em todos os fatos narrados pelos autores dos Atos Apócrifos, mas não creio que estaríamos muito distante do que alguns cristãos pensavam serem os riscos da vida sexual ativa. Mesmo que as hipérboles fossem amenizadas, não estaríamos muito longe do que poderia ter sido a ascese cristã de alguns grupos cristãos primitivos alternativos.

\section{Fontes primárias}

PIÑERO, A. \& CERRO, G. Hechos apócrifos de los apóstoles I: Hechos de Andrés, Juan y Pedro. Madrid: Biblioteca de Autores Cristianos, 2004.

PIÑERO, A. \& CERRO, G. Hechos apócrifos de los apóstoles II: Hechos de Pablo y Tomás. Madrid: Biblioteca de Autores Cristianos, 2005. 
PIÑERO, A. \& CERRO, G. Hechos apócrifos de los apóstoles III: Hechos de Filipe, Martirio de Pedro, Hechos de Andrés y Mateo, Martirio de Mateo, Hechos de Pedro, Viajes y martírio de Bernabé, Hechos de Tadeo, Hechos de Juan, por Prócoro, Hechos de Santiago el Mayor, Hechos de Santiago, Simón y Judas, Milagros de Juan, Pasión de Bartolomé, Martirio de Nereo y Aquiles, Martirio de Andrés. Madrid: Biblioteca de Autores Cristianos, 2011.

\section{Referências bibliográficas}

CASTRO, E. Vocabulário de Foucault: um percurso pelos seus temas, conceitos e autores. Belo Horizonte: Autêntica, 2009.

FOUCAULT, M. História da sexualidade 3: o cuidado de si. Rio de Janeiro: Graal, 1985.

FOUCAULT, M. História da sexualidade 2: o uso dos prazeres. Rio de Janeiro: Graal, 1998.

FOUCAULT, M. História da sexualidade 1: a vontade de saber. Rio de Janeiro: Graal, 1999.

FOUCAULT, M. Sexualidade e solidão. In: MOTTA, M. B.(Org.). Michel Foucault: ética, sexualidade, política. Rio de Janeiro: Forense Universitária, 2004a. (Coleção Ditos e Escritos V).

FOUCAULT, M. A escrita de si. In: MOTTA, M. B. (Org.). Michel Foucault: ética, sexualidade, política. Rio de Janeiro: Forense Universitária, 2004b. (Coleção Ditos e Escritos V).

FOUCAULT, M. Em defesa da sociedade: curso no Collège de France (1975-1976). São Paulo: Martins Fontes, 2005.

FOUCAULT, M. O jogo de Michel Foucault. In: MOTTA, M. B. (Org.). Michel Foucault: genealogia da ética, subjetividade e sexualidade. Rio de Janeiro: Forense Universitária, 2014. (Coleção Ditos e Escritos IX).

IPIRANGA, P. A concepção de páthos em relatos híbridos na antiguidade: José e Aseneth e os Atos de Paulo e Tecla. Disponível em: <file://C:/Users/alfredoliva/Documents/LEITURAS/ Apócrifos/A\%20 concepção\%20de\%20pathos\%20em\%20relatos\%20híbridos\%20da\%20 antiguidade,\%20Pedro\%20Ipiranga\%20Júnior.pdf>. Acesso em 19 fev. 2016.

KAESTLI, J. D. \& MARGUERAT, D. (Orgs.). O mistério apócrifo: introdução a uma literatura desconhecida. São Paulo: Loyola, 2012.

KOESTER, H. Introdução ao novo testamento: 2. história e literatura do cristianismo primitivo. São Paulo: Paulus, 2005.

MOUNCE, W. D. Léxico analítico do Novo Testamento grego. São Paulo: Vida Nova, 2013. 
PATTERSON, S. J. The Gospel of Thomas and christian origins: essays on the Fifth Gospel. Boston: Brill, 2013.

PIOVANELLI, P. What is a christian apocryphal text and how does it work? Some observations on apocryphal hermeneutics. Nederlands Theologisch Tijdschrift, Groningen, n. 59, p. 31-40, 2005.

RUSCONI, C. Dicionário do grego do Novo Testamento. São Paulo: Paulus, 2003.

TREVIJANO, R. A Bíblia no cristianismo antigo: pré-nicenos, gnósticos, apócrifos. São Paulo: Ave Maria, 2009. 